\title{
Migraine and peripheral inflammation
}

\author{
Migren ve periferik inflamasyon
}

Aynur Yilmaz Avci ${ }^{1 *}$, Oktay Akalin ${ }^{1}$

1.Department of Neurology, Baskent University Hospital, Alanya-Antalya, Turkey

\section{ABSTRACT}

Aim: Migraine is a common headache disorder that may be associated with inflammation and vascular diseases. We evaluated C-reactive protein and the number of immune cells in the peripheral blood of young adult patients with migraine.

Patients and Methods: This case-control study included 520 subjects: 260 patients with migraine (without aura, 169 patients; with aura, 91 patients) and 260 healthy control subjects (age range, 18-50 years). Participants had no known anemia, vascular risk factors, or inflammatory diseases. We evaluated serum C-reactive protein and complete blood count parameters in patients with migraine and control subjects.

Results: C-reactive protein level, leukocyte, neutrophil, lymphocyte, platelet counts and mean platelet volume significantly differed in patients with migraine compared to controls $(P<0.001)$. However, with the exception of $C$-reactive protein, these parameters were similar in migraine with and without aura. Logistic regression analysis showed that migraine was significantly associated with $\mathrm{C}$-reactive protein level (odds ratio [OR], 2.36; 95\% confidence interval [Cl], 1.73-3.23; $\mathrm{P}<0.001)$, MPV (OR, 2.32; $95 \% \mathrm{Cl}, 1.78-3.0 ; \mathrm{P}<0.001)$, and leukocyte count (OR, 1.61; 95\% Cl, 1.32-1.94;).

Conclusion: Increased levels of peripheral inflammation may occur in patients with migraine and may be involved in the pathogenesis of migraine.

Keywords: Complete blood count, C-reactive protein, headache, leukocyte, lymphocyte, platelet

\section{ÖZET}

Amaç: Migren inflamasyon ve vasküler hastalıklar ile ilişkili olabilen yaygın bir baş ağrısı türüdür. Biz genç erişkin migren hastalarında C-reaktif protein ve periferik kandaki bağışıklık hücre sayısını değerlendirdik.

Hastalar ve Yöntem: Bu olgu-kontrol çalışması, 260 migren hastası (aurasız, 169 olgu, auralı, 91 olgu) ve 260 sağlıklı kontrol katılımcı (yaş aralığı, 18-50 yıl) olmak üzere 520 kişiyi içermektedir. Katılımcıların hiçbirinde bilinen bir anemi, vasküler risk faktörü veya inflamatuar hastalık yoktu. Migren ve kontrol olgularında serum C-reaktif protein ve tam kan sayımı parametrelerini değerlendirdik.

Bulgular: C-reaktif protein, lökosit, nötrofil, lenfosit, trombosit sayıları ve ortalama trombosit hacmi migren hastalarında kontrol grubuna $(P<0.001)$ oranla anlaml olarak farklıydı. Ancak bu parametreler, C-reaktif protein hariç, auralı ve aurasız migrenlerde benzerdi. Lojistik regresyon analizinde migren hastalığı C-reaktif protein seviyesi (OR, 2.36; $95 \% \mathrm{Cl}, 1.73$ ile $3.23 ; \mathrm{P}<0.001$ ), ortalama trombosit hacmi (odds ratio [OR], 2.32; 95\% confidence interval [CI], $1.78-3.0 ; P<0.001$ ), ve lökosit sayıSI $(\mathrm{OR}, 1.61 ; 95 \% \mathrm{Cl}, 1.32$ - 1.94; $\mathrm{P}<0.001)$ ile anlamlı olarak ilişkiliydi.

Sonuç: Periferik inflamasyonun artmış seviyeleri migren hastalarında ortaya çıkabilir ve migren patogenezinde rol oynayabilir.

Anahtar Kelimeler: Tam kan sayımı, C-reaktif protein, baş ağıısı, lökosit, lenfosit, trombosit, 
$\mathbf{M}$ igraine is a common complaint encountered in neurology and internal medicine clinics. Several large epidemiological studies showed that the prevalence of migraine in the general population ranges from $6-13 \%$ [1]. Migraine is considered to be a neurovascular disorder. Repeated migraine attacks are associated with inflammatory arteriopathy of the cranial vessels $[2,3]$. In genetically predisposed individuals, activation of brainstem structures or a cortical spreading depression phenomenon are thought to activate the trigeminovascular system. This trigeminal activation results in the release of vasoactive peptides from presynaptic nerve terminals, which induces vasodilatation and neurogenic inflammation in leptomeningeal and extracranial vessels [4-6]. The sterile neurogenic inflammatory model suggests the involvement of the immune system in migraine. Activated immune cells produce large amounts of cytokines that could stimulate the activation of trigeminal nerves, the release of vasoactive peptides or other biochemical mediators, and then aggravate neurogenic inflammation $[2,3,6]$. Both humoral and cellular components of the immune system have been studied in migraine; however, there have been many conflicting reports regarding this issue [7].

Specific abnormalities of inflammatory marker levels in the systemic circulation have been observed in migraine, including increased levels of $\mathrm{C}$-reactive protein (CRP), interleukins, and adhesion molecules $[2,8]$. $\mathrm{CRP}$ is a marker of inflammation that may predict subclinical atherosclerosis, and its levels are increased in vascular diseases and in healthy individuals without cardiovascular disease $[9,10]$. Previous studies reported associations between CRP levels and migraine $[11,12]$. The immune cells in peripheral blood (i.e., leukocytes, neutrophils, and lymphocytes) play roles in peripheral inflammatory responses and atherosclerotic processes $[13,14]$. The circulating leukocyte count provides a measure of inflammatory status and has been proposed to be a potential biomarker for cardiovascular risk prediction $[14,15]$. Neutrophils are proinflammatory cells, detected within atherosclerotic plaque, which release and synthesize chemokines, cytokines, and growth factors [14]. Lymphocytes are involved in regulation of immune responses. Lymphocytes secrete proinflammatory cytokines that promote atherosclerosis and activate inflammation, and may also modulate atherogenesis [16].

Platelets are an important link between inflammation, thrombosis, and atherogenesis. Platelets interact with the endothelium and leukocytes, and release mediators that stimulate inflammation $[17,18]$. Increased platelet activation has been described in migraine patients during and between headache episodes [19,20]. In migraine, proinflammatory platelet adhesion to leukocytes occurs during the headache-free interval, similar to observations in acute coronary and cerebrovascular syndromes [20]. Platelet activation and aggregation were shown to be increased in migraineurs [19]. The relationship between migraine and vascular disease is poorly understood. We hypothesized that the immune system and inflammation may play roles in migraine disease. Therefore, the present study was performed to evaluate CRP and the number of immune cells in the peripheral blood of in patients with migraine in comparison to controls.

\section{PATIENTS AND METHODS}

\section{Study population}

This case-control clinical study was performed in patients with newly diagnosed migraine at the Baskent Medical Faculty Neurology Outpatient Clinic. Inclusion criteria were: duration of migraine symptoms $\geq 1$ year; headache frequency $\geq 2$ attacks/month; and absence of any known vascular risk factors, inflammatory disease, chronic illness, metabolic disease, or infections. Exclusion criteria were: (1) migraine duration < 1 year; (2) history of cerebrovascular or cardiovascular disease; (3) arterial hypertension (blood pressure > 130/80 mm Hg); (4) diabetes mellitus; (5) hyperlipidemia (low-density lipoprotein (LDL) cholesterol $\geq 160$ $\mathrm{mg} / \mathrm{dL}$ ); (6) body mass index $<18 \mathrm{~kg} / \mathrm{m} 2$ or $>30 \mathrm{~kg} /$ m2; (7) abnormal plasma CRP level (> $10 \mathrm{mg} / \mathrm{L}$ ); (8) cigarette smoking $>1 \mathrm{pack} /$ day; (9) current pregnancy or lactation; (10) substance abuse; (11) use of drugs, such as antiplatelet agents, anticoagulants, statins, or hormonal drugs; (12) renal, metabolic, inflammatory, infectious, or immune disease; (13) malignancy with or without chemotherapy or radiation treatment; or (14) history of anemia, recent anemia treatment, thrombocytosis, or thrombocytopenia. In addition, patients with high CRP levels ( $\geq 10 \mathrm{mg} / \mathrm{L})$ were excluded from the study because high levels of CRP may represent nonspecific inflammation and lack positive predictive value [9]. Patients were included if they had previously used $<3$ tablets per week of medications for acute pain, such as acetaminophen, nonsteroidal anti-inflammatory drugs, triptans, or caffeine; patients with daily use 
of analgesics were excluded. Patients using migraine prophylaxis with drugs such as propranolol, topiramate, or valproic acid were also excluded. A total of 350 consecutive migraine patients were initially considered for the study, and 90 patients were excluded (anemia, $\mathrm{n}=35$; infection, $\mathrm{n}=18$; thyroid disease, $\mathrm{n}=15$; CRP $\geq 10 \mathrm{mg} / \mathrm{L}, \mathrm{n}=10$; lack of laboratory tests, $\mathrm{n}=7$; and LDL cholesterol > $160 \mathrm{mg} / \mathrm{L}, \mathrm{n}=5$ ). The other 260 consecutive, newly diagnosed migraine patients, consisting of 200 women (77\%) and 60 men (23\%) (age range, $18-50$ years; mean, $32 \pm 7$ years), were included in the study.

Healthy control subjects (260 subjects), including 192 women (79\%) and 68 men (26\%) (age range, 18-50 years; mean, $32 \pm 7$ years), were recruited consecutively from among hospital staff, laboratory staff, relatives of patients, and the general population. Inclusion criteria for control subjects were: (1) absence of headaches, such as migraine, tension-type headache, or cluster headache; and (2) no other neurological or systemic disease. Exclusion criteria for control subjects were the same as for the migraine group.

This study was evaluated and determined to be exempt from the requirement for informed consent by the Baskent University Institutional Review Board due to its retrospective study design

\section{Evaluation}

Patients were diagnosed as having migraine according to the criteria of the International Classification of Headache Disorders III [22]. A detailed history of migraine was obtained, including disease duration (years), age at onset, average duration of current headache (h), presence of aura, trigger factors, accompanying symptoms, frequency per month, and location and severity of pain. Headache severity was evaluated on a visual analog scale (VAS; range of pain severity: 1 [minimum] to 10 [maximum]). Migraine headache attack frequency was defined as the number of attacks per month. All patients and control subjects received complete physical and neurological examinations. Comorbidities (coronary artery disease, stroke, diabetes mellitus, or thyroid disease) and intercurrent illnesses, such as respiratory or urinary infections, were determined from the patient history, physical examination, and laboratory tests (biochemical and hematological tests). Blood pressure, body weight, height, smoking habit, and education level were recorded for all migraine patients and control subjects.

\section{Complete blood count}

Routine hematological analysis was performed in our laboratory on the samples from the migraine and control groups. Blood samples were obtained from the antecubital vein during a headache-free period. To exclude the potential effects of a previous attack, migraine patients had been free of migraine attacks for $\geq 3 \mathrm{~d}$ and had not taken any medication within $3 \mathrm{~d}$ before blood sampling. The samples for complete blood count were collected into tubes containing ethylenediaminetetraacetic acid (EDTA) and processed within $1 \mathrm{~h}$ after venipuncture. The samples were stored at room temperature during the period between venipuncture and processing. The blood samples in EDTA tubes were analyzed using electrical impedance and optical fluorescence methods in an automated hematology analysis device (CELL-DYN Ruby ${ }^{\mathrm{TM}}$; Diagnostic Systems, Abbott Park, IL). Hematological parameters included leukocyte count (reference range, $4.5-11 \times \mathrm{bin} / \mu \mathrm{L}$ ), neutrophil count $(2-6.9 \times \mathrm{bin} / \mu \mathrm{L})$, lymphocyte count (0.6-3.4 × 109/L), hemoglobin level (female, 12-16.5 $\mathrm{g} / \mathrm{dL}$; male, $13.5-17.50 \mathrm{~g} / \mathrm{dL})$, platelet count (140-440 $\times$ bin $/ \mu \mathrm{L}), \mathrm{MPV}(0-99.9 \mathrm{fL})$, and red cell distribution width (RDW) (11.6-17\%).

\section{CRP}

Blood samples were obtained from the antecubital vein from control subjects and during a headache-free period from migraine patients. Phlebotomy tubes contained no anticoagulant. Blood was centrifuged at 3,000 $\times \mathrm{g}$ for 10 minutes and stored at $-20^{\circ} \mathrm{C}$ until analysis. Serum CRP was measured by latex-enhanced immune turbidimetry using a monoclonal anti-CRP antibody (Architect c800; Abbott) (CRP reference level, $\leq 5$ $\mathrm{mg} / \mathrm{L})$.

\section{Statistical analysis}

Data analysis was performed with statistical software (IBM SPSS for Windows, version 21.0; IBM Corp., Armonk, NY,USA). Continuous variables are reported as means \pm standard deviation (SD) or median (range, minimum to maximum). Categorical variables are reported as number (\%). Normality of the continuous variables was evaluated by the Shapiro-Wilk test. Differences in continuous variables between the two groups were determined by independent samples t-test or Mann-Whitney test. Comparisons for $>2$ groups were performed with a one-way analysis of variance (ANOVA) or Kruskal-Wallis test. Categorical variables were 
compared with Pearson's chi-square or Fisher's exact test. Relationships between continuous variables were determined with Spearman's rank correlation and Pearson's product moment correlation. Multiple regression analysis was used to investigate factors affecting MPV and CRP, with logarithmic transformation of skewed variables. Factors affecting migraine disease were investigated with logistic regression. In all analyses, $\mathrm{P}<$ 0.05 was taken to indicate statistical significance.

\section{RESULTS}

Among the 260 consecutive, newly diagnosed migraine patients included in the study, 169 (65\%) had migraine without aura and 91 (35\%) had migraine with aura. Migraine headache characteristics and comparisons of $\mathrm{CBC}$ and $\mathrm{CRP}$ parameters in the migraine and control groups are shown in Table 1 . The CRP levels, mean platelet counts, leukocyte counts, neutrophil counts, lymphocyte counts, MPV, and RDW were similar between migraine patients with and without aura $(P>0.05)$. There were no significant differences in VAS score, headache localization, attack duration, headache frequency, medication, education, or smoking habit between migraine patients with and without aura $(\mathrm{P}>0.05)$.The sex-related differences in migraine and control groups are shown in Table 2.

The leukocyte count was significantly correlated with neutrophil count, but CRP was correlated with neutrophil count and body mass index in the migraine group (Table 3). In subgroup analysis of migraine disease, leukocyte counts were correlated with neutrophils and lymphocytes in migraine with and without aura (Table 4). However, CRP was correlated with neutrophil count in migraine with aura, but correlated with body mass index in migraine with and without aura (Table 4).

The logistic regression analysis showed significant associations of migraine with CRP (odds ratio $[\mathrm{OR}], 2.36 ; 95 \%$ confidence interval [CI], 1.733.23; $\mathrm{P}<0.001$ ), MPV (OR, 2.32; 95\% CI, 1.78-3.0; $\mathrm{P}<0.0001)$, and leukocyte count (OR, 1.61; 95\% CI, 1.32-1.94; $\mathrm{P}<0.001)$ compared with control subjects. However, in the multiple linear regression analysis, CRP $(\mathrm{P}<0.001)$, MPV $(\mathrm{P}<0.001)$, leukocyte count $(\mathrm{P}<0.001)$, and platelet count $(\mathrm{P}<0.001)$ remained independent parameters affecting migraine.

\section{DISCUSSION}

The present study was performed to evaluate CRP and complete blood count parameters in migraine. Complete blood count parameter data fell within the normal ranges in migraine and control groups. CRP level, lymphocyte, neutrophil, leukocyte, and platelet counts were significantly higher in migraine patients than in the control group (Table 1). CRP was increased by 2.36 -fold and leukocyte count by 1.61-fold in migraine patients compared with controls. The high CRP level, relative leukocytosis, lymphocytosis, and thrombocytosis may represent a chronic inflammatory state during the pain-free period, emphasizing the role of chronic inflammation in the pathophysiology of migraine. In this setting, the neurogenic inflammation proposed for migraine could be exacerbated in migraine headache with systemic alterations detectable in peripheral blood.

In this study, despite being within the respective normal reference ranges, leukocyte, neutrophil, and lymphocyte counts were significantly higher in patients with migraine than in control subjects (Table 1). These findings are consistent with the results of previous studies $[21,23]$. In contrast to the present study, earlier studies indicated that the peripheral lymphocyte count did not change significantly after a spontaneous migraine attack. The sample sizes of these studies were smaller than that of our study $[24,25]$. Increases in lymphocyte count represent a longer standing process of inflammation indicative of immunological activation in migraine patients. The acute-phase leukocyte subset (as indicated by the increased neutrophil fraction attached to platelets) in migraine suggests that increased inflammatory signaling occurs even during the quiescent phase [20].

In this study, NLR was higher in female patients with migraine compared with males with migraine (Table 2). In a previous study, NLR was shown to increase during migraine attacks [26]. We measured NLR in the headache-free period and our study population was larger than that in the previous study. These findings suggest hormone-dependent male/female differences in inflammatory cells in migraine $[27,28]$.

In addition, platelet counts were higher in female subjects and in migraine patients, consistent with previous studies [26,29]. In other studies, platelet volume and size were similar in patients with migraine and controls $[30,31]$. However, these studies had smaller sample sizes than our study. Female sex hormones have 
Table 1. Characteristics of participants in the migraine and control groups*

\begin{tabular}{|c|c|c|c|c|}
\hline \multicolumn{2}{|l|}{ Characteristic } & Control $(n=260)$ & Migraine (n=169) & $P$ \\
\hline \multicolumn{2}{|l|}{ Age (years) } & $\begin{array}{l}31.5 \pm 6.7 \\
31(18-48)\end{array}$ & $\begin{array}{l}31.7 \pm 6.7 \\
32(18-49)\end{array}$ & NS \\
\hline Sex & $\begin{array}{l}\text { Female } \\
\text { Male }\end{array}$ & $\begin{array}{l}192(73.8 \%) \\
68(26.2 \%)\end{array}$ & $\begin{array}{l}200(76.9 \%) \\
60(23.1 \%)\end{array}$ & NS \\
\hline \multirow{4}{*}{ Education level (scholl) } & Elementary & $82(31.5 \%)$ & $80(30 \%)$ & \multirow{4}{*}{ NS } \\
\hline & Secondary & $23(8.8 \%)$ & $25(9.6 \%)$ & \\
\hline & High & $72(27.7 \%)$ & $77(29.6 \%)$ & \\
\hline & University & $83(31.9 \%)$ & $76(29.2 \%)$ & \\
\hline \multicolumn{2}{|l|}{ Body mass index $(\mathrm{kg} / \mathrm{m} 2)$} & $\begin{array}{l}24.4 \pm 2.9 \\
24.4(18.2-29.8)\end{array}$ & $\begin{array}{l}24.5 \pm 3.4 \\
24.7(18.3-29.8)\end{array}$ & NS \\
\hline \multicolumn{2}{|l|}{ Family history of headache } & $62(23.8 \%)$ & $203(78.1 \%)$ & 0.0001 \\
\hline \multicolumn{2}{|l|}{ Smoking $(\leq 1 \mathrm{pack} / \mathrm{d})$} & $69(26.6 \%)$ & $75(28.8 \%)$ & NS \\
\hline \multicolumn{2}{|l|}{ C-reactive protein $(\mathrm{mg} / \mathrm{L})$} & $\begin{array}{l}0.8 \pm 0.5 \\
0.7(0.02-3.6)\end{array}$ & $\begin{array}{l}1.9 \pm 1.8 \\
1.2(0.09-9.7) \\
\end{array}$ & 0.0001 \\
\hline \multicolumn{2}{|l|}{ Mean platelet volume (fL) } & $\begin{array}{l}7.5 \pm 1.02 \\
7.5(4.91-12.00)\end{array}$ & $\begin{array}{l}8.4 \pm 1.2 \\
8.2(6.31-12.6)\end{array}$ & 0.0001 \\
\hline \multicolumn{2}{|l|}{ Mean platelet volume $\geq 8 \mathrm{fL}$} & $75(28.8 \%)$ & $100(59.2 \%)$ & 0.0001 \\
\hline \multicolumn{2}{|l|}{ Hemoglobin $(\mathrm{g} / \mathrm{dL})$} & $\begin{array}{l}13.5 \pm 1.1 \\
13.4(12.0-17.5)\end{array}$ & $\begin{array}{l}13.6 \pm 1.1 \\
13.4(12.0-17.0)\end{array}$ & NS \\
\hline \multicolumn{2}{|l|}{ Platelet count $(\mathrm{K} / \mu \mathrm{L})$} & $\begin{array}{l}255.7 \pm 51.8 \\
257(150-369) \\
\end{array}$ & $\begin{array}{l}268.01 \pm 53.1 \\
262(150-400) \\
\end{array}$ & 0.007 \\
\hline \multicolumn{2}{|l|}{ Leukocyte count $(\mathrm{bin} / \mu \mathrm{L})$} & $\begin{array}{l}6.5 \pm 1.2 \\
6.2(4.50-10.30)\end{array}$ & $\begin{array}{l}7.5 \pm 1.4 \\
7.4(4.5-10.30)\end{array}$ & 0.0001 \\
\hline \multicolumn{2}{|l|}{ Neutrophil count $(\mathrm{bin} / \mu \mathrm{L})$} & $\begin{array}{l}3.6 \pm 0.9 \\
3.5(1.81-6.79)\end{array}$ & $\begin{array}{l}4.3 \pm 1.03 \\
4.2(2.11-6.78)\end{array}$ & 0.0001 \\
\hline \multicolumn{2}{|l|}{ Lymphocyte count $(\mathrm{bin} / \mu \mathrm{L})$} & $\begin{array}{l}2.1 \pm 0.4 \\
2.1(1.08-3.58)\end{array}$ & $\begin{array}{l}2.4 \pm 0.5 \\
2.4(1.27-4.21) \\
\end{array}$ & 0.0001 \\
\hline \multicolumn{2}{|l|}{ Neutrophil/lymphocyte ratio } & $\begin{array}{l}1.7 \pm 0.5 \\
1.6(0.85-4.72) \\
\end{array}$ & $\begin{array}{l}1.8 \pm 0.5 \\
1.7(0.9-3.7) \\
\end{array}$ & NS \\
\hline \multicolumn{2}{|l|}{ Red cell distribution width (\%) } & $\begin{array}{l}14.2 \pm 1.5 \\
14.5(7.30-20) \\
\end{array}$ & $\begin{array}{l}15.3 \pm 9.2 \\
15 .(10.9-17.0)\end{array}$ & NS \\
\hline \multicolumn{2}{|c|}{ Migraine disease duration(years) } & & $7.82 \pm 6.25(1-0)$ & \\
\hline \multirow{2}{*}{ Headache localization } & Half head & & $83(31.9 \%)$ & \\
\hline & Entire head & & $177(68.1 \%)$ & \\
\hline VAS score & & & $7.7 \pm 1.7(3-10)$ & \\
\hline $\begin{array}{l}\text { Headache frequency (num- } \\
\text { ber/month) }\end{array}$ & & & $\begin{array}{l}7.11 \pm 5.6 \\
6(2-20)\end{array}$ & \\
\hline \multirow{4}{*}{ Medication } & Acetaminophen & & $75(28 \%)$ & \\
\hline & NSAID & & $148(56.9 \%)$ & \\
\hline & Ergotamine & & $21(8.1 \%)$ & \\
\hline & Triptan & & $16(6.2 \%)$ & \\
\hline
\end{tabular}

${ }^{*}$ Data are reported as the number (\%), mean \pm standard deviation (SD), or median (range, minimum to maximum). Abbreviations: NS, not significant; NSAID, nonsteroidal antiinflammatory drug; VAS, visual analog scale.

been shown to be positively associated with platelet count in migraine [28]. Hormonal differences between females and males may affect platelets and thrombocytopoiesis [32]. In this study, we observed a weak inverse correlation between platelet count and MPV in migraine patients without aura $(\mathrm{r}=-0.269 ; \mathrm{P}=0.0001)$.
Consistent with our study, a previous report indicated a higher platelet count and slightly lower MPV in females than in males, and the increase in MPV in males was not sufficient to compensate for the lower platelet count [33]. Enhanced platelet activation in migraine patients is a marker of the inflammatory process in the 
Table 2. Sex-related differences in the migraine and control groups*

\begin{tabular}{|c|c|c|c|c|c|c|}
\hline \multirow{3}{*}{$\begin{array}{l}\text { Parameter } \\
\text { Mean platelet vol- } \\
\text { ume (fL) }\end{array}$} & \multicolumn{3}{|l|}{ Control (n=260) } & \multicolumn{3}{|l|}{ Migraine $(n=260)$} \\
\hline & Female (n=192) & \multirow{2}{*}{$\begin{array}{l}\text { Male }(\mathrm{n}=68) \\
7.68 \pm 1.01(6-11.9)\end{array}$} & \multirow{2}{*}{$\begin{array}{l}\mathrm{P} \\
\mathrm{NS}\end{array}$} & Female $(\mathrm{n}=200)$ & \multirow{2}{*}{$\begin{array}{l}\text { Male }(n=60) \\
8 \pm 1(6.35-11.60)\end{array}$} & \multirow{2}{*}{$\begin{array}{l}\mathrm{P} \\
\mathrm{NS}\end{array}$} \\
\hline & $\begin{array}{l}7.47 \pm 1.03 \\
12.0)\end{array}$ & & & $\begin{array}{l}8.43 \pm 1.20 \quad(6.31- \\
12.60)\end{array}$ & & \\
\hline $\begin{array}{l}\text { Platelet count }(\mathrm{K} / \\
\mu \mathrm{L})\end{array}$ & $\begin{array}{ll}264.71 \pm 51.5 & (150- \\
394) & \\
\end{array}$ & $\begin{array}{ll}230.04 \pm 43.7 \quad(150- \\
319) & \end{array}$ & 0.001 & $\begin{array}{l}273.92 \pm 53.06(150- \\
400)\end{array}$ & $249 \pm 49(163-400)$ & 0.001 \\
\hline $\begin{array}{l}\text { Leukocyte count } \\
(\mathrm{bin} / \mu \mathrm{L})\end{array}$ & $6.43 \pm 1.18(4.5-9.8)$ & $\begin{array}{l}6.67 \pm 1.35 \\
10.3)\end{array}$ & NS & $7.41 \pm 1.41(4.5-0.9)$ & $7 \pm 1(4.5-10.3)$ & NS \\
\hline $\begin{array}{l}\text { Neutrophil count } \\
(\text { bin } / \mu \mathrm{L})\end{array}$ & \begin{tabular}{|l|}
$3.61 \pm 0.88$ \\
$6.72)$
\end{tabular} & $\begin{array}{l}3.75 \pm 1.09 \\
6.79)\end{array}$ & NS & $\begin{array}{l}4.32 \pm 1.04 \\
6.78)\end{array}$ & $4 \pm 1(2.31-6.05)$ & NS \\
\hline $\begin{array}{l}\text { Lymphocyte count } \\
(\mathrm{bin} / \mu \mathrm{L})\end{array}$ & $\begin{array}{l}2.14 \pm 0.44 \\
3.27)\end{array}$ & $\begin{array}{l}2.13 \pm 0.54 \quad(1.08- \\
3.58)\end{array}$ & NS & $\begin{array}{l}2.39 \pm 0.56 \\
4.21)\end{array}$ & $2.5 \pm 0.6(1.45-3.69)$ & NS \\
\hline $\begin{array}{l}\text { C-reactive protein } \\
(\mathrm{mg} / \mathrm{L})\end{array}$ & $\begin{array}{l}0.75 \pm 0.49 \\
2.78)\end{array}$ & $\begin{array}{l}0.97 \pm 0.69 \\
2.60)\end{array}$ & $0.025 \S$ & $\begin{array}{l}1.93 \pm 1.97 \quad(0.15- \\
9.73)\end{array}$ & $\begin{array}{l}1.75 \pm 1.55 \\
7.30)\end{array}$ & NS \\
\hline Hemoglobin (g/dL) & $\begin{array}{l}13.05 \pm 0.69 \quad(12.0- \\
15.0)\end{array}$ & $\begin{array}{l}15.06 \pm 0.96 \\
17.5)\end{array}$ & 0.0001 & $13.2 \pm 0.8(12-15.7)$ & $15 \pm 1(12.2-17)$ & 0.0001 \\
\hline $\begin{array}{l}\text { Red cell distribution } \\
\text { width (\%) }\end{array}$ & $\begin{array}{l}14.12 \pm 1.60 \\
20.0)\end{array}$ & $\begin{array}{l}14.5 \pm 1.27 \\
17.0)\end{array}$ & NS & $\begin{array}{l}15.48 \pm 10.43 \quad(10.9- \\
17.0]\end{array}$ & $\begin{array}{ll}14.88 \pm 1.14 \\
16.7)\end{array}$ & NS \\
\hline $\begin{array}{l}\text { Neutrophil/1ym- } \\
\text { phocyte ratio }\end{array}$ & $\begin{array}{ll}1.73 \pm 0.47 & (0.85- \\
3.37) & \\
\end{array}$ & $\begin{array}{ll}1.87 \pm 0.78 & (0.88- \\
4.72) & \\
\end{array}$ & NS & $\begin{array}{l}1.87 \pm 0.52 \quad(1.02- \\
3.7)\end{array}$ & $\begin{array}{ll}1.65 \pm 0.45 & (0.94- \\
2.66) & \\
\end{array}$ & 0.007 \\
\hline
\end{tabular}

${ }^{*}$ Data are reported as the number $(\%)$, mean $\pm \mathrm{SD}$, or median (range, minimum to maximum).

Table 3. Relationship of leukocytes and C-reactive protein (CRP) with measured parameters in patients with migraine *

\begin{tabular}{|l|l|l|l|l|}
\hline Parameter & Leukocyte $(\mathrm{n}=260)$ & \multicolumn{2}{l|}{ CRP $(\mathrm{n}=260)$} \\
\hline & $\mathrm{r}$ & $\mathrm{P}$ & $\mathrm{r}$ & $\mathrm{P}$ \\
\hline CRP & 0.209 & $0.001 \dagger$ & - & - \\
\hline Mean platelet volume & -0.030 & $\mathrm{NS}$ & -0.026 & $\mathrm{NS}$ \\
\hline Leukocyte count & - & - & 0.209 & $0.001 \dagger$ \\
\hline Neutrophil count & 0.889 & 0.000 & 0.257 & $0.0001^{*}$ \\
\hline Lymphocyte count & 0.698 & 0.000 & 0.069 & NS \\
\hline Neutrophil/lymphocyte ratio & 0.186 & $0.003 \dagger$ & 0.172 & $0.006 \dagger$ \\
\hline Hemoglobin & 0.021 & $\mathrm{NS}$ & -0.019 & NS \\
\hline Platelet count & 0.197 & $0.001 \dagger$ & 0.162 & $0.009 \dagger$ \\
\hline Red cell distribution width & -0.091 & $\mathrm{NS}$ & 0.069 & NS \\
\hline Migraine disease duration & -0.020 & $\mathrm{NS}$ & 0.102 & NS \\
\hline Headache frequency & 0.032 & NS & -0.041 & NS \\
\hline VAS score & 0.015 & NS & 0.007 & NS \\
\hline Headache duration & -0.093 & NS & -0.045 & NS \\
\hline Body mass index & 0.085 & NS & 0.275 & $0.0001^{*}$ \\
\hline
\end{tabular}

*Data are reported as the correlation coefficient, $r$, between leukocyte count and parameter, and between CRP and parameter. Abbreviations: NS, not significant; VAS, visual analog scale. $†$ Negligible values.

trigeminovascular system and cellular interaction rather than a precipitating factor in migraine pathogenesis [20].

The high MPV levels in migraine patients observed in the present study were consistent with the results of a previous report [34]. MPV was 2.32-fold higher in migraine patients than in control subjects. In contrast to the present study, previous studies indicated no correlation between MPV and migraine, but the sample sizes were smaller than that in our study [30,31]. In another study, the mean age of participants was higher than that in the present study, and no information was provided about the headache characteristics or vascular disease risk factors in patients with migraine [31]. In the present study, inclusion criteria ensured that hea- 
Table 4. Relationship of leukocytes and CRP with measured parameters in patients with migraine with and without aura*

\begin{tabular}{|c|c|c|c|c|c|c|c|c|}
\hline \multirow[t]{3}{*}{ Parameter } & \multicolumn{2}{|c|}{ Migraine without aura $(\mathrm{n}=169)$} & \multicolumn{2}{|c|}{ Migraine with aura $(\mathrm{n}=91)$} & \multicolumn{2}{|c|}{ Migraine without aura $(n=169)$} & \multicolumn{2}{|c|}{ Migraine with aura $(\mathrm{n}=91)$} \\
\hline & \multicolumn{4}{|c|}{ Leukocyte } & \multicolumn{4}{|l|}{ CRP } \\
\hline & $\mathbf{r}$ & $P$ & $\mathbf{r}$ & $\mathbf{P}$ & $\mathbf{r}$ & $P$ & $\mathrm{R}$ & $P$ \\
\hline CRP & 0.204 & $0.008 \dagger$ & 0.226 & $0.031 \dagger$ & - & - & - & - \\
\hline $\begin{array}{l}\text { Mean platelet } \\
\text { volume }\end{array}$ & -0.046 & NS & -0.027 & NS & -0.077 & NS & 0.064 & NS \\
\hline $\begin{array}{l}\text { Le u k o c y te } \\
\text { count }\end{array}$ & - & - & - & - & 0.204 & $0.008 \dagger$ & 0.226 & $0.031 \dagger$ \\
\hline $\begin{array}{l}\text { Neutrophil } \\
\text { count }\end{array}$ & 0.876 & 0.000 & 0.916 & 0.000 & 0.231 & $0.003 \dagger$ & 0.302 & $0.004^{*}$ \\
\hline $\begin{array}{l}\text { Lymphocyte } \\
\text { count }\end{array}$ & 0.722 & 0.000 & 0.656 & 0.000 & 0.055 & NS & 0.105 & NS \\
\hline $\begin{array}{l}\text { Neutrophil/ } \\
\text { lymphocyte } \\
\text { ratio }\end{array}$ & 0.105 & NS & 0.345 & 0.001 & 0.164 & $0.033 \dagger$ & 0.174 & NS \\
\hline Hemoglobin & 0.145 & NS & 0.197 & NS & 0.041 & NS & -0.101 & NS \\
\hline Platelet count & 0.266 & 0.000 & 0.070 & NS & 0.193 & $0.012 \dagger$ & 0.115 & $0.009 \dagger$ \\
\hline $\begin{array}{l}\text { Red cell distri- } \\
\text { bution width }\end{array}$ & -0.052 & NS & -0.186 & NS & 0.070 & NS & 0.094 & NS \\
\hline $\begin{array}{l}\text { Migraine dis- } \\
\text { ease duration }\end{array}$ & 0.037 & NS & -0.004 & NS & 0.119 & NS & 0.037 & NS \\
\hline $\begin{array}{l}\text { Headache fre- } \\
\text { quency }\end{array}$ & 0.034 & NS & 0.051 & NS & 0.064 & NS & -0.092 & NS \\
\hline VAS score & 0.079 & NS & -0.084 & NS & 0.032 & NS & -0.082 & NS \\
\hline $\begin{array}{l}\text { Headache du- } \\
\text { ration }\end{array}$ & -0.122 & NS & -0.029 & NS & -0.097 & NS & 0.043 & NS \\
\hline $\begin{array}{l}\text { Body mass in- } \\
\text { dex }\end{array}$ & 0.148 & NS & -0.031 & NS & 0.268 & $0.0001^{*}$ & 0.283 & $0.007^{*}$ \\
\hline
\end{tabular}

*Data reported as correlation coefficient, $r$, between leukocyte and parameter, and between CRP and parameter in patients with migraine with and without aura. Abbreviations: NS, not significant; VAS, visual analog scale. †Negligible values.

dache frequency was $\geq 2$ attacks/month and migraine disease duration was $>1$ year. Elevated MPV is associated with increased platelet production and platelet turnover. These findings could reflect higher rates of platelet turnover in migraine and may be related to increased production of bone marrow-derived, larger circulating reticulated platelets within the peripheral blood [35].

Consistent with previous reports, CRP levels were elevated in migraine patients in the present study $[11,12]$. In contrast to the present study, a previous report indicated that CRP levels were similar between migraine patients and control subjects. However, this previous report did not eliminate vascular risk factors or concomitant disease, and the mean age of participants was higher than that in our study [36]. Elevated CRP level is a marker of inflammation and subclinical atherosclerosis $[9,10]$. High CRP levels may reflect the inflammatory status in migraine.
The pathophysiological process that underlies trigeminal activation in migraine is a matter of debate. Cortical spreading depression in the occipital cortex stimulates the nerve endings of the trigeminal system surrounding the pial vessels. Sarchielli et al. described downregulation of leukocyte function antigen expression by $\mathrm{CD} 4+$ and $\mathrm{CD} 8+$ lymphocytes evaluated from the internal jugular blood of migraine patients without aura during attacks parallel to transient increases in tumor necrosis factor alfa, interleukin-6, and soluble intercellular adhesion molecule. This structural alteration would be an attempt to antagonize the transvascular migration of lymphocytes in a reaction to sterile inflammation in the dura mater [8]. Increased platelet activation results in upregulation of specific binding to leukocytes, which promotes proinflammatory leukocyte secretion and their tethering to the endothelium, a mechanism that has been demonstrated in stroke and which could provide a link to migraine. Enhanced platelet activation in migraine patients is a marker of the 
inflammatory process in the trigeminovascular system and cellular interactions rather than a precipitating factor in migraine pathogenesis [20].

A unique feature of the present study design was the assessment of the associations of CRP and complete blood count parameters in nonobese young adult migraine patients. The participants had no known anemia, vascular risk factors, or inflammatory disease. Limitations of the present study included the absence of measurements of other platelet-activating factors, such as thromboxane A2 and beta-thromboglobulin, or leukocyte and lymphocyte subtypes. Comparison of the results with levels of other thrombotic and inflammation markers may provide an improved understanding of migraine pathophysiology.

In conclusion, increased levels of peripheral inflammation may occur in migraine disease and may be involved in its pathogenesis.

Declaration of conflicting interests: The authors declared no conflicts of interest with respect to the authorship and/or publication of this article.

Funding: The authors received no financial support for the research and/or authorship of this article.

Acknowledgements: The authors thank Hakan Gökahmetoğlu and Sevinç Türk for collecting data.

\section{REFERENCES}

1. Lipton RB, Stewart WF, Diamond S, Diamond ML, Reed M. Prevalence and burden of migraine in the United States: data from the American Migraine Study II. Headache 2001;41(7):646-57

2. Waeber C, Moskowitz MA. Migraine as an inflammatory disorder. Neurology. 2005;64(10 Suppl 2):S9-S15.

3. Bolay H, Reuter U, Dunn AK, Huang Z, Boas DA, Moskowitz MA. Intrinsic brain activity triggers trigeminal meningeal afferents in migraine model. Nat Med. 2002;8(2):136-42.

4. Moskowitz MA. The neurobiology of vascular head pain. Neurology. 1984;16(2):157168.

5. Markowitz S, Saito K, Moskowitz MA. Neurogenically mediated leakage of plasma protein occurs from blood vessels in dura mater but not brain. J Neurosci. 1987;7(12):4129-36.

6. Goadsby PJ, Edvinsson L, Ekman R. Vasoactive peptide release in the extrecerebral circulation of humans during migraine headache. Ann Neurol. 1990;28(2):183-7.

7. Kemper RH, Meijer WJ, Korf J, Ter Horst GJ. Migraine and function of the immune system: a meta-analysis of clinical literature published between 1966 and 1999. Cephalalgia. 2001;21(5):549-57

8. Sarchielli P, Alberti A, Baldi A, Coppola F, Rossi C, Pierguidi L, et al. Proinflammatory cytokines, adhesion molecules, and lymphocyte integrin expression in the internal jugular blood of migraine patients without aura assessed ictally. Headache. 2006;46(2):200-7.

9. Bassuk SS, Rifai N, Ridker PM. High-sensitivity C-reactive protein: clinical importance. Curr Probl Cardiol. 2004;29(8):439-93.

10. Emerging Risk Factors Collaboration, Kaptoge S, Di Angelantonio E, Pennells L, Wood $\mathrm{AM}$, White IR, Gao P, et al. C-reactive protein, fibrinogen, and cardiovascular disease prediction. N Engl J Med. 2012;367(14):1310-20.

11. Vanmolkot $\mathrm{FH}$, de Hoon $\mathrm{JN}$. Increased C-reactive protein in young adult patients with migraine. Cephalalgia. 2007;27(7):843-846.

12. Yilmaz Avci A, Lakadamyali H, Arikan S, Benli US, Kilinc M. High sensitivity C-reactive protein and cerebral white matter hyperintensities on magnetic resonance imaging in migraine patients. J Headache Pain. 2015;16:9.

13. Phillipson M, Kubes P. The neutrophil in vascular inflammation. Nat Med. 2011;17(11):1381-90.

14. Soehlein O. Multiple roles for neutophils in atherosclerosis. Circ Res. 2012;110(6):87588.

15. Libby P, Nahrendorf M, Swirski FK. Leukocytes link local and systemic inflammation in ischemic cardiovascular disease: an expanded "Cardiovascular Continuum." J Am Coll Cardiol. 2016;67(9):1091-103.

16. Lahoute $\mathrm{C}$, Herbin $\mathrm{O}$, Mallat $\mathrm{Z}$, Tedgui A. Adaptive immunity in atherosclerosis: mechanisms and future therapeutic targets. Nat Rev Cardiol. 2011;8(6):348-58.

17. Kaplan ZS, Jackson SP. The role of platelets in atherothrombosis. Hematology Am Soc Hematol Educ Program. 2011;2011:51-81.

18. Gawaz M, Langer H, May AE. Platelets in inflammation and atherogenesis. J Clin Invest. 2005;115(12):3378-84

19. Danese E, Montagnana M, Lippi G. Platelets and migraine. Thromb Res. 2014;134(1):17-22.

20. Zeller JA, Frahm K, Baron R, Stingele R, Deuschl G. Platelet-leukocyte interaction and platelet activation in migraine: a link to ischemic stroke? J Neurol Neurosurg Psychiatry. 2004;75(7):984-7.

21. Forcelini CM, Dantas DC, Luz C, Santin R, Stein AT, Barros HM, Barea LM. Analysis of leukocytes in medication-overuse headache, chronic migraine, and episodic migraine. Headache. 2011;51(8):1228-38.

22. Headache Classification Subcommittee of the International Headache Society. The International Classification of Headache Disorders: 2nd edition. Cephalalgia. 2004;24(suppl 1):9-160.

23. Cseh A, Farkas KM, Derzbach L, Muller K, Vasarhelyi B, Szalay B, Treszi A, Farkas V. Lymphocyte subsets in pediatric migraine. Neurol Sci. 2013;34(7):1151-5.

24. Leone M, Biffi M, Leoni F, Bussone $G$. Leukocyte subsets and cortisol serum levels in patients with migraine without aura and chronic tension-type headache. Cephalalgia. 1994;14(2):139-42.

25. Gilman-Sachs A, Robbins L, Baum L. Flow cytometric analysis of lymphocyte subsets in peripheral blood of chronic headache patients. Headache. 1989;29(5):290-4.

26. Karabulut KU, Egercioglu TU, Uyar M, Ucar Y. The change of neutrophils/lymphocytes ratio in migraine attacks: a case-controlled study. Ann Med Surg. 2016;27(10):52-6.

27. Rathod KS, Kapil V, Velmurugan S, Khambata RS, Siddique U, Khan S, Van Eijl S, Gee LC, Bansal J, Pitrola K, Shaw C, D'Acquisto F, Colas RA, Marelli-Berg F, Dalli J, Ahluwalia A. Accelerated resolution of inflammation underlies sex differences in inflammatory responses in humans. J Clin Invest. 2017;127(1):169-82.

28. Zhou P, Meng Z, Liu M, Ren X, Zhu M, He Q, et al. The associations between leukocyte, erythrocyte or platelet, and metabolic syndrome in different genders of Chinese. Medicine. 2016;95(44):e5189.

29. Nelson KB, Richardson AK, He J, Lateef TM, Khoromi S, Merikangas KR. Headache and biomarkers predictive of vascular disease in a representative sample of US children. Arch Pediatr Adolesc Med. 2010;164(4):358-62.

30. Pradalier A, Abuaf N, Launay JM, Vincent $D$. Platelet size and volume distribution measured by automated platelet analyzer. Cephalalgia. 1992;12(5):321-2.

31. Peatfield RC, Gawel MJ, Guthrie DL, Pearson TC, Glover V, Littlewood J, et al. Platelet size: no correlation with migraine or monoamine oxidase activity. J Neurol Neurosurg Psychiatry. 1982;45(9):826-9.

32. Butkiewicz AM, Kemona H, Dymicka-Piekarska V, Matowicka-Karna J, Radziwon P, Lipska A. Platelet count, mean platelet volume and thrombocytopoietic indices in healthy women and men. Thromb Res. 2006;118(2):199-204.

33. Bain BJ. Platelet count and platelet size in males and females. Scand J Haematol. 1985;35(1):77-9.

34. Varol S, Akıl E, Çevik MU, Çelepkolu T, Yücel Y, Tanrıverdi MH, Aluçlu MU, Uzar E. Migrenli hastaların kanında ortalama trombosit hacmi ve trombosit sayısının araştıııması. Turk J Neurol. 2013;23(2):90-2.

35. McCabe DJ, Harrison P, Sidhu PS, Brown MM, Machin SJ. Circulating reticulated platelets in the early and late phases after ischaemic stroke and transient ischaemic attack. Br J Haematol. 2004;126(6):861-9.

36. Gudmundsson LS, Aspelund T, Scher Al, Thorgeirsson G, Johannsson M, Launer LJ, et al. C-reactive protein in migraine sufferers similar to that of non-migraineurs: the Reykjavik Study. Cephalalgia. 2009;29(12):1301-10.

How to cite this article/Bu makaleye atıf için: Avci AY, Akalin O. Migraine and peripheral inflammation. Acta Med. Alanya 2017;1(3): 20-27 